\title{
アイソトープ追跡に依る乳房內乳汁カゼイン の合成機構に関古る研究
}

\author{
I $\mathrm{Ca}^{45}$ 注射による追跡
}

前野正久 人有馬倰六郎・志賀勝治・紊藤善一

(北海道大学毠学部)

$$
\text { 古师二郎・金子元三・須具新太郎 }
$$

(北海道大学理学部)

高田稳・高津定雄・松村晄

(北海道立滰川樰羊場)

Studies on the synthetic mehanism of milk casein in mamma with

tracing of Isotope

I Tracing with $\mathrm{Ca}^{45}$

M. Mafino, S. Arima, K. Shiga and Z. Sarto

(Faculty of Agriculture, Hokkaido University)

Z. Furuichi, M. Kaneko and S. Sugal

(Faculty of Science, Hokkaido University)

M. Yoshida, S. Takatsu and A. Matsumura.

(Hokkaido Takikawa Sheep Breeding Farm)

\section{I 緒言}

予報に於て報告し心如く睌に山羊頸静胍の注射によっ

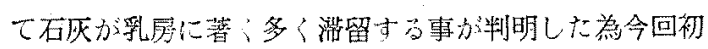

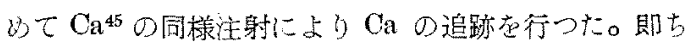
$\mathrm{Ca}^{45}$ の血液及乳房内乳汁の分布特にカゼイン苍主しして

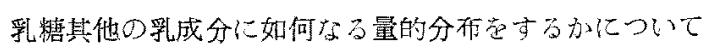
实駼觉行つたのて茹心報告する。

\section{II 実験材料並方法}

供試山羊は北海道立潼川種羊場飼育の泌乳中の3 5 才のもの在使用し，時に岕才イペスチン注射により泌乳 中の処女山羊を用い。

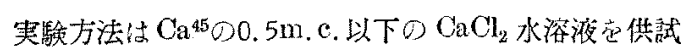
山羊の项静脈に注射し一定時間毎に頸静脈血, 乳静脈洫 及び乳房内より注射針による採乳採血更に䆣乳による分

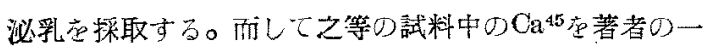
人の改良しだ計数器にかけて測定した。次に乳汁は酸， レンネット其他によつてカゼイン，アルブミン等に分割

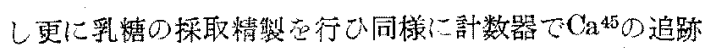
它行つた。

日畜会報，25，(1)

\section{III 実験結果}

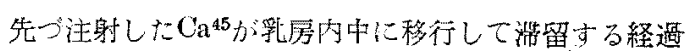
莡注射後 5 分方方 27 時間の間 8 回に分けて乳汁中のCa

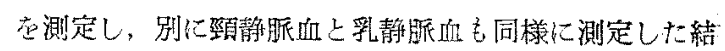
果は次表の如々である。

第 1 表 $\mathrm{Ca}^{45}$ 注射による山羊乳及び血液中の迫跡 Count $/ \mathrm{mins} / \mathrm{c} . \mathrm{c}$.

\begin{tabular}{|c|c|c|c|c|c|c|}
\hline & & & 新 & 71 & 孚静眡血 & 政静脈血 \\
\hline 注 & 舅 & 前 & & $36^{*}$ & $36^{*}$ & $36^{*}$ \\
\hline \multirow{3}{*}{ 注 } & 5 & 分 & & 35 & 36 & 36 \\
\hline & 30 & $" 1$ & & 40 & 36 & 40 \\
\hline & 60 & 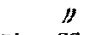 & . & 44 & 38 & 38.5 \\
\hline \multirow{2}{*}{ 射 } & 2 & 腈 & & 51 & - & 40 \\
\hline & 5 & J & & 96 & - & - \\
\hline \multirow{3}{*}{ 嵝 } & 11 & $\not \nu$ & & 56 & - & - \\
\hline & 17 & 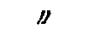 & & 40 & - & - \\
\hline & 27 & $\|$ & & 37 & $\longrightarrow$ & - \\
\hline
\end{tabular}

備考 自然係数は $32 *$ 第二回は10c.c. 老測定

上表で明な梯に $\mathrm{Ca}^{45}$ は注射後30分で乳汁中に移行し始 》27時間即方約 1 日で消失する。

次に注射 30 分後でも $\mathrm{Ca}^{45}$ は乳静脈血には增加せず殆ん ご乳房内にC C $a^{45}$ が满留する事がわかる。

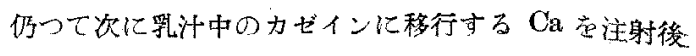




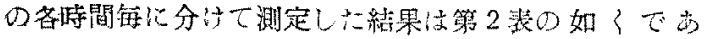
万o

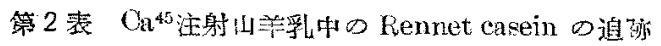

\begin{tabular}{|c|c|c|c|c|c|}
\hline & & 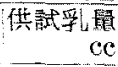 & 測定酒 & 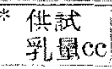 & 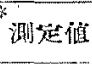 \\
\hline \multirow[t]{2}{*}{ 注 } & 前! & -5 & 32 & -1 & - \\
\hline & 分 & 5 & 32 & - & - \\
\hline \multirow[t]{2}{*}{ 注 } & 30 & 9 & 336 & - & - \\
\hline & 60 & 3 & 384 & - & - \\
\hline \multirow[t]{2}{*}{ 射 } & 2 時間 & 10 & 1216 & 10 & 1088 \\
\hline & $6 j$ & 10 & 736 & 10 & 2362 \\
\hline \multirow[t]{2}{*}{ 後 } & $12 \mathrm{~J}$ & 10 & 528 & - & - \\
\hline & $16 \mathrm{p}$ & 10 & 240 & - & - \\
\hline
\end{tabular}

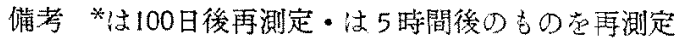
上表の如々供試乳量上測定値からレンネソトカゼイン

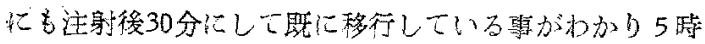
間で最諳量赤している。

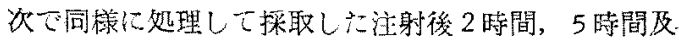

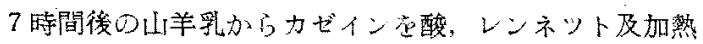

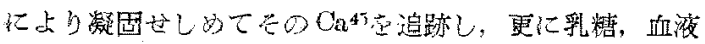

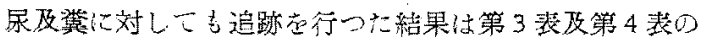

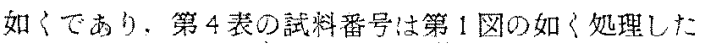
ものてる。

第3表 山关新计中 $0 \mathrm{Ca}^{45}$ 追荡

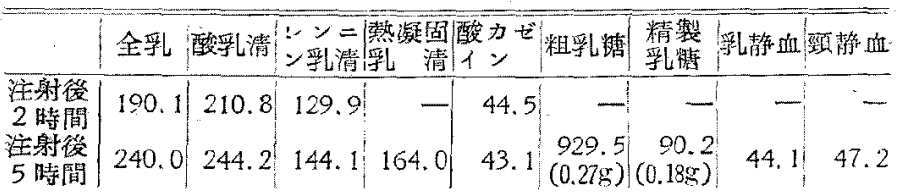

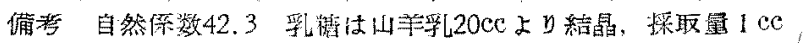

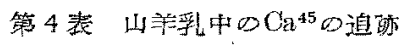

\begin{tabular}{|c|c|c|c|c|c|c|}
\hline \multirow{2}{*}{$\begin{array}{l}\text { 誠料 } \\
\text { 量写 }\end{array}$} & \multicolumn{2}{|c|}{ 注射 2 赫間媵 } & \multicolumn{2}{|c|}{4 時闌後 } & \multicolumn{2}{|c|}{7 特閔㣭 } \\
\hline & 湘点賢 & 湖定褀 & 澌觉㟟 & 湖谁倠 & 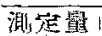 & 湘定谁 \\
\hline (1) & 1 & & 1 & 109.0 & 0. & \\
\hline & 0.1 & 5 & 0.10 & 87 & 0,098 & \\
\hline 18 & 0.04 & 30 & 0.04 & 64 & 0.073 & \\
\hline 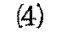 & & & c. & 4 & 0.1 & \\
\hline & & 65. & & & $1 \mathrm{c}$ & \\
\hline$(6$ & $0.0993 \mathrm{~g}$ & 41.4 & $0.0979 \mathrm{~g}$ & 59.1 & $0.0984 \mathrm{~g}$ & \\
\hline & 1 c.c. & 49.5 & lc.c. & 56.9 & 100 & \\
\hline
\end{tabular}

(9) $\quad 0.0365 \mathrm{~g} 2181.8: 0.0625 \mathrm{~g}: 2341.5 .0 .0355 \mathrm{~g}: 2341.5$

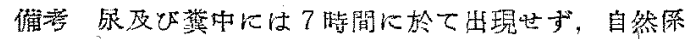
数34.5 原注射液 $0.1 \mathrm{c} . \mathrm{c} .4430 .3$

以上の結果に上り酸力ゼィンに注石灰殆儿じ結合甘ず 反つて乳裙と石兏方緢合している事がわかる。

次に熱凝固乳清はレンニン孚清上引年多量に $\mathrm{Ca}^{45}$ 裳 含有しているが己はレンネットの凝固てカゼインが多量

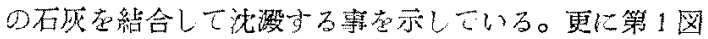

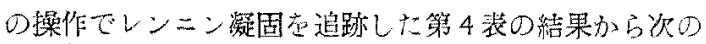

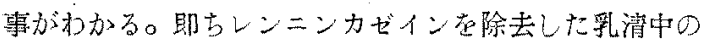
残余の石疢は，力ゼイン以外の他の蛋白とは殆んど結合

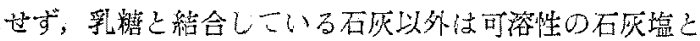

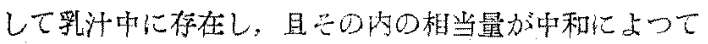

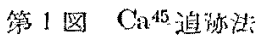

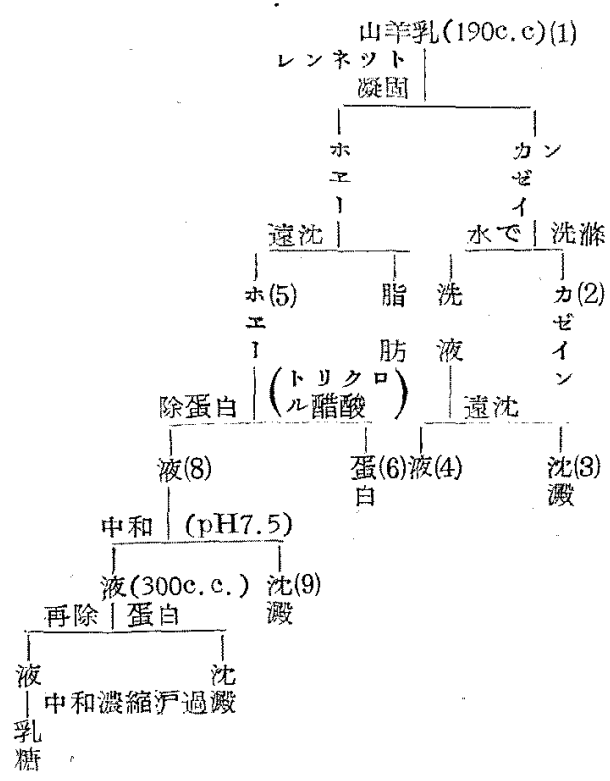

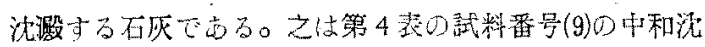
搌物 $0.0365 \mathrm{~g}$ が218200測定值点示した 事から判然ししている。面してこの沈溳

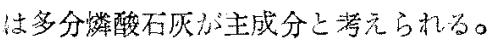

以上て必乳山羊に注射したCa年方一定

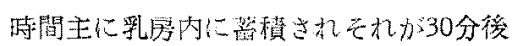
に估乳计中のカゼインや一成分として泌

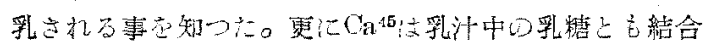

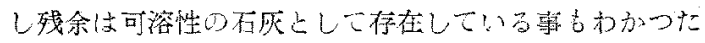
Dです。

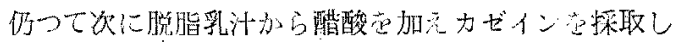

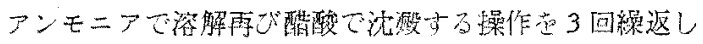

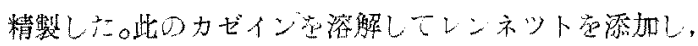
パラカゼインに变化せしめ之に種々の量の $\mathrm{Ca}$ を添加し

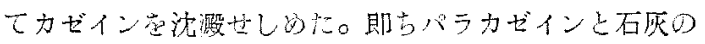

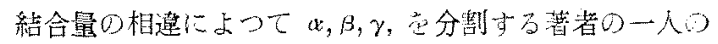

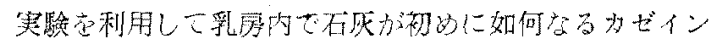

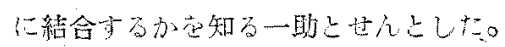

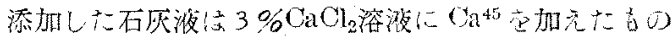

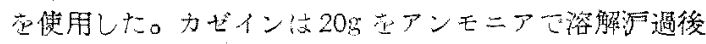

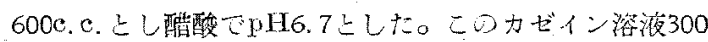

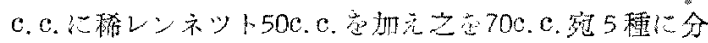

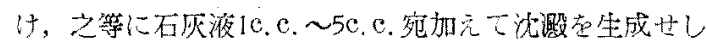

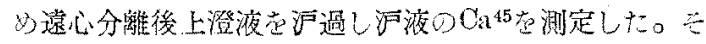
の結果は次表の如孝のでする。 


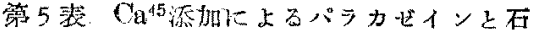
灰の綪合资化

\begin{tabular}{|c|c|c|c|}
\hline $\mathrm{CaCl}_{2}$ 浱加鼠 & 沏 渥 & 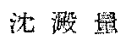 & 沪液の睡楚低 \\
\hline lc.c. & - & - & 187 \\
\hline $2 \mathrm{c} . \mathrm{c}$. & + (百沺) & 0.007 & 227 \\
\hline $3 \mathrm{c} . \mathrm{c}$. & H & 0.115 & 265 \\
\hline $4 c . c$. & $H$ & 0.130 & 352 \\
\hline $5 \mathrm{c} . \mathrm{c}$. & H & 0.350 & 540 \\
\hline
\end{tabular}

備暂 石灰液 I C.c. 1324 自然係数 57

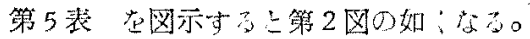

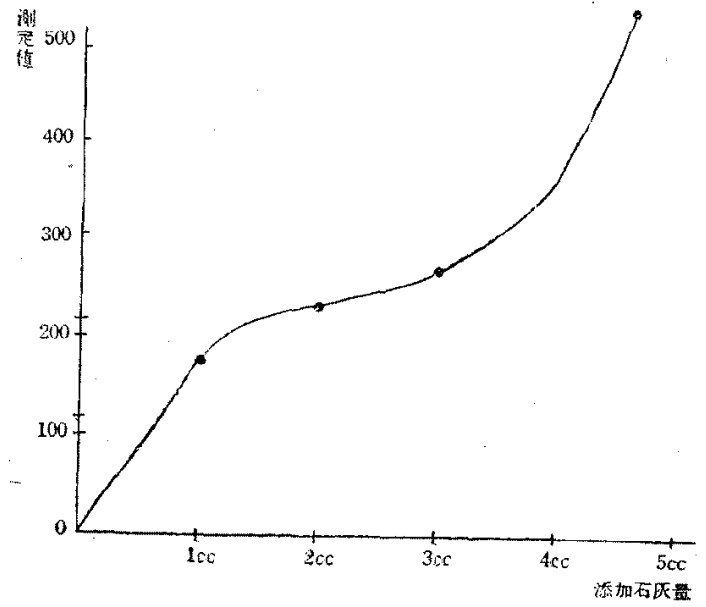

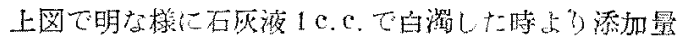

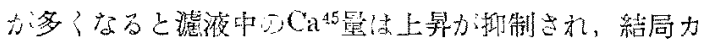

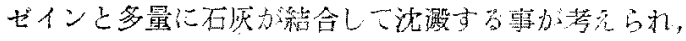

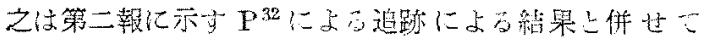

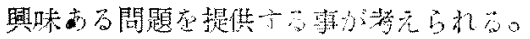

\section{IV 総括並考察}

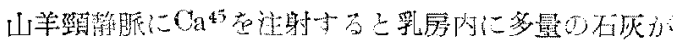

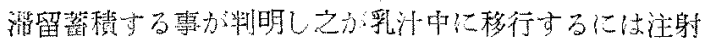

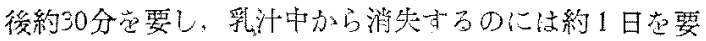

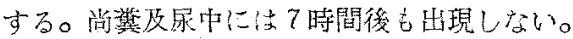

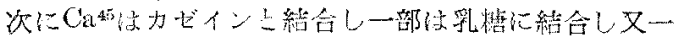

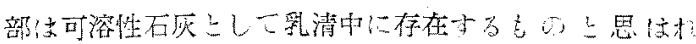

30

次に乳汁にCa正加えてカゼイン在レンニン凝固せし

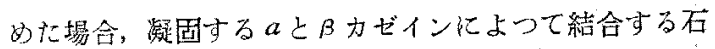

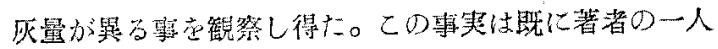
が牛乳カゼインの化学的分割によつて知り得た事であ り，之か今回の実駼によつて明にされたのである而し て乳防内乳腺中に入つた石灰が初如何なるカゼイン゙

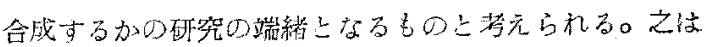

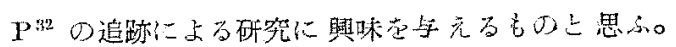

\section{$\mathbf{V}$ 結 論}

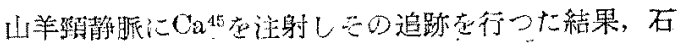

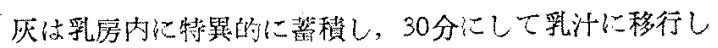
䄪24時間にして消失方方。

乳汁内で络石灰はカゼイン上結合し且乳糖上も結合す る。更侸残余は可溶性石灰乞して乳清中心存在する。

(1953.11.9.罗付)

\section{文献}

1）前野正久等 (1954)：日畜会報24（4），171

2) Nordso (1935) : Biol. Chem. 128, 745

3) Atren \& Heyn (1950) : Am. J. Physid. 162, 570

4) Hevesy (1948) : Radioactive Indicators Interscience Publishers. New York, London

\section{Résumé}

Studies on the synthetic mechanism of milk casein in mamma with tracing of Isotope was began with tracing of $\mathrm{Ca}^{45}$ in goat's venons injection.

Ca in blood is accumulated remarkably in mammary gland and after 30 minutes $\mathrm{Ca}$ removes into milk, but its Ca disappears after 27 hours.

In milk Ca combines with casein and lactose, and residue exists in milk serum as soluble matter.

\section{外国交献抄録}

Quantitative threonine requirememt of the weanling pig.

W. M. BEESON, H. D. JACRSON \& E. T. MERTZ (1953) : J. Auimal. Sci. 12, 870 $-875$

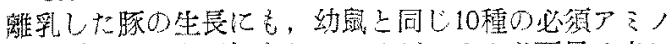

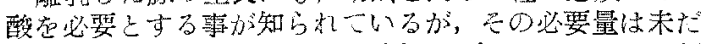

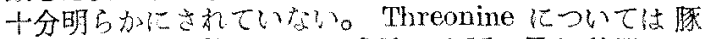

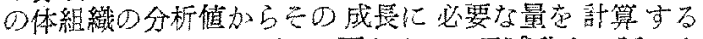

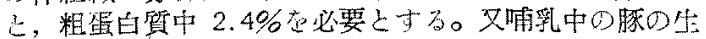

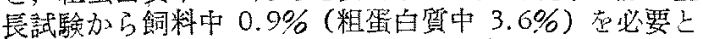

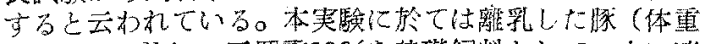

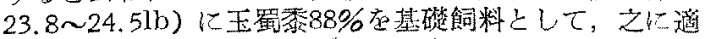

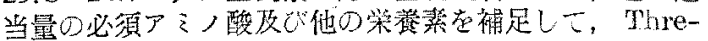

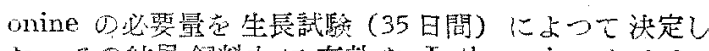

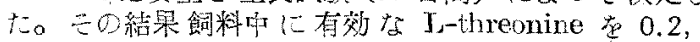
$0.4 ， 0.5,0.6$ 及び $0.7 \%$ 含有せしめだ時に，0.2\%で

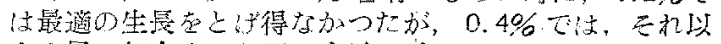
上の量に相步すると同し生唇宗した。而してこの量は

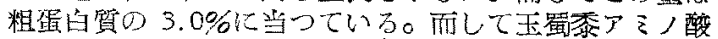

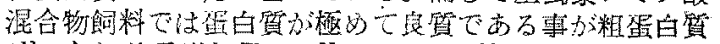

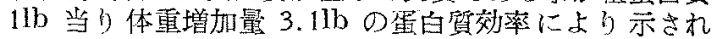

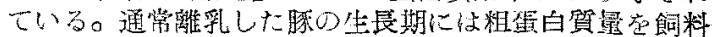
中の18\%上されているか，適当な量と平均のとれた必須 ア乏，酸密補足した場合には体重 $251 \mathrm{~b}$ の離乳した豚は

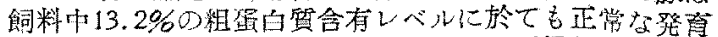

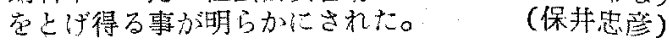

